\title{
Bleomycin-Treated Chimeric Thy1-Deficient Mice with Thy1-Deficient Myofibroblasts and Thy-Positive Lymphocytes Resolve Inflammation without Affecting the Fibrotic Response
}

\author{
Pazit Y. Cohen, ${ }^{1}$ Raphael Breuer, ${ }^{1,2}$ Philip Zisman, ${ }^{1}$ and Shulamit B. Wallach-Dayan ${ }^{1}$ \\ ${ }^{1}$ Lung Cellular and Molecular Biology Laboratory, Institute of Pulmonary Medicine, Hadassah-Hebrew University Medical Center, \\ Jerusalem 91120, Israel \\ ${ }^{2}$ Department of Pathology, Boston University School of Medicine, Boston, MA 02118, USA
}

Correspondence should be addressed to Shulamit B. Wallach-Dayan; wallach-dayan@hadassah.org.il

Received 25 December 2014; Revised 31 March 2015; Accepted 21 April 2015

Academic Editor: Peter Huszthy

Copyright (c) 2015 Pazit Y. Cohen et al. This is an open access article distributed under the Creative Commons Attribution License, which permits unrestricted use, distribution, and reproduction in any medium, provided the original work is properly cited.

\begin{abstract}
Lung fibrosis is characterized by abnormal accumulation of fibroblasts in the interstitium of the alveolar space. Two populations of myofibroblasts, distinguished by Thyl expression, are detected in human and murine lungs. Accumulation of Thyl-negative $\left(\right.$ Thyl $^{-}$) myofibroblasts was shown in the lungs of humans with idiopathic pulmonary fibrosis (IPF) and of bleomycin-treated mice. We aimed to identify genetic changes in lung myofibroblasts following Thyl crosslinking and assess the impact of specific lung myofibroblast Thyl-deficiency, in vivo, in bleomycin-injured mouse lungs. Thyl increased in mouse lung lymphocytes following bleomycin injury but decreased in myofibroblasts when fibrosis was at the highest point (14 days), as assessed by immunohistochemistry. Using gene chip analysis, we detected that myofibroblast Thyl crosslinking mediates downregulation of genes promoting cell proliferation, survival, and differentiation, and reduces production of extracellular matrix (ECM) components, while concurrently mediating the upregulation of genes known to foster inflammation and immunological functions. Chimeric Thyl-deficient mice with Thyl ${ }^{+}$lymphocytes and Thyl ${ }^{-}$myofibroblasts showed fibrosis similar to wild-type mice and an increased number of CD4/CD25 regulatory T cells, with a concomitant decrease in inflammation. Lung myofibroblasts downregulate Thy1 expression to increase their proliferation but to diminish the in vivo inflammatory milieu. Inflammation is not essential for evolution of fibrosis as was previously stated.
\end{abstract}

\section{Background}

Idiopathic pulmonary fibrosis (IPF) is a nonneoplastic pulmonary disease characterized by the formation of scar tissue within the lungs, in the absence of any known provocation $[1,2]$. Fibroblasts are central to both wound healing and the pathogenesis of organ tissue fibrosis. Although it remains unclear whether fibroblast proliferation is the primary mechanism of pathogenesis in IPF or whether it is a reactive process to another form of lung tissue damage, selective deletion of fibroblasts is sufficient to prevent fibrosis after injury [3]. The intratracheal instillation (IT) of bleomycin into mice is used as an in vivo experimental model to study underlying mechanisms of lung fibrosis and inflammation [4].
Lung fibroblasts can be divided into subpopulations on the basis of size and shape, cytokine profiles, lipid content, and cell surface protein expression $[5,6]$. The most extensively characterized in vitro model of fibroblast heterogeneity is based on surface expression of Thyl $[5,7]$. It has been shown in mice and humans that Thyl-positive $\left(\right.$ Thyl $\left.^{+}\right)$and Thylnegative $\left(\mathrm{Thyl}^{-}{ }^{-}\right.$) fibroblasts differ with respect to cytokine $[8-12]$ and growth factor responses $[13,14]$, as well as cell migration patterns [15].

Thyl is a $25-37 \mathrm{kD}$ glycosylphosphatidylinositol- (GPI-) anchored cell surface protein that belongs to the immunoglobulin-like gene super family [16]. Thyl is expressed and distributed differently among species and among tissues of the same species; however, it is present on brain cells and fibroblasts of all species studied thus far [17]. In mice, Thyl 
is also found on other cell types, including thymocytes and peripheral $\mathrm{T}$ cells $[17,18]$. The wide distribution of Thy1 suggests that it has distinct functions in different tissues and species. Immune cells such as T lymphocytes were previously reported to be involved in both the attenuation and the promotion of fibrosis. These contradictory observations are most likely a reflection of the phenotypic heterogeneity of involved T cells, as reviewed by Re et al. [19] and Luzina et al. [20].

In this study, we aimed to define the molecules and pathways involved in inflammation and fibrosis that are affected by Thyl crosslinking on lung myofibroblasts in vitro and specifically by its deficiency in lung myofibroblasts in vivo, in the experimental model of bleomycin-induced fibrosis in mouse lungs, excluding the role of Thyl on lymphocytes.

\section{Materials and Methods}

2.1. Animals. Male, 11 to 12 weeks old, C57BL/6J mice (Jackson Laboratory, Bar Harbor, ME) and C57BL/6J Thyl-deficient mice (kindly provided by Professor R. J. Morris, Laboratory of Neurobiology, National Institute for Medical Research, London, UK) were used.

At 12-14 weeks, body weight for the two types of mice was similar. Histological sections of lung, heart, brain, colon, liver, and kidney were studied. No differences were noted in histological sections or in lung hydroxyproline contents for the two types. Bronchoalveolar cellularity was also similar in terms of the number of cells per $\mathrm{mL}$, with $99 \%$ macrophages, and $1 \%$ lymphocytes or neutrophils.

All animal procedures were approved by the Hebrew University-Hadassah Medical School Animal Care Committee. Mice were housed in a specific pathogen-free environment.

\subsubsection{Chimeric Mice and Lymphoid Organ Cell Transplanta-} tion. We created a C57BL/6J Thyl-deficient chimeric mouse containing wild-type (WT) (Thyl ${ }^{+}$) lymphoid organ cells. Lymphoid tissues in the Thyl-deficient mice were ablated, and the mice were reconstituted with hematopoietic cells isolated from WT mouse lymphoid organs as we previously performed and detailed [21]. WT mice reconstituted with hematopoietic cells isolated from lymphoid organs of WT mice served as control group. One day prior to cell transplantation, 6-week-old C57BL/6 mice were subjected to total body irradiation ( $750 \mathrm{cGy}$, dose rate of $179 \mathrm{cGy} / \mathrm{min}$ ) delivered by a linear accelerator (Clinac G6, Varian Medical Systems, Palo Alto, CA, USA) with a source-to-skin distance of $80 \mathrm{~cm}$. One day after irradiation, mice received syngeneic lymphoid organ cells (spleen and lymph nodes, 50-100 $\times 10^{6}$ ) obtained from WT- C57BL/6-based mice. Following adoptive transfer (30 days) and engraftment confirmation by FACS analysis (Figure 3(a)), chimeric mice were subjected to intratracheal instillation (IT) of bleomycin.

2.2. Intratracheal Instillation. Mice were anesthetized by intraperitoneal (IP) injection of $0.05-0.07 \mathrm{~mL}$ of $40 \mathrm{mg} / \mathrm{mL}$ ketamine (Ketalar, Parke-Davis, Pontypool, Gwent, UK) and $0.5 \mathrm{mg} / \mathrm{mL}$ droperidol (Inapsine, Janssen Pharmaceutica,
Beerse, Belgium). The skin and subcutaneous tissues overlying the proximal portion of the trachea were exposed by a $5 \mathrm{~mm}$ transverse incision to allow for direct external visualization of the trachea. A metal cannula fitted to a tuberculin syringe was carefully passed into the trachea. A dose of 0.06-0.08 units of bleomycin (H. Lundbeck, Copenhagen, Denmark) dissolved in $0.1 \mathrm{~mL}$ of saline solution, or $0.1 \mathrm{~mL}$ of saline alone, was slowly injected.

2.3. Quantitative Assessment of Fibrotic Lung Injury. Mice were killed with a lethal dose of pentobarbital at 1, 3, 7, or 14 days after IT bleomycin. The abdominal aorta was transected, and the animal was exsanguinated. To eliminate blood, lungs were perfused with normal saline through the right ventricle and bronchoalveolar lavage (BAL) was performed. A polyethylene cannula (PE 205; Clay Adams, Parsippany, NJ, USA) was placed in the trachea, and $3 \mathrm{~mL}$ of normal saline was slowly injected and withdrawn.

Lung injury was assessed quantitatively, as we have previously described [22] by bronchoalveolar lavage (BAL) cellularity, semiquantitative morphological index (SMI) studies of lung fibrosis, and quantitative lung collagen measurements.

2.4. Lung Collagen. Lung collagen was assessed in the right lung using the Sircol Collagen Assay kit (Biocolor, Belfast, Northern Ireland), as described previously [23, 24]. This method measures newly synthesized collagen that has not been extensively cross-linked. Briefly, the upper lobe of the right lung was homogenized in $5 \mathrm{~mL}$ of 0.5 molar acetic acid containing $1 \mathrm{mg}$ pepsin (Sigma Aldrich, St Louis, MO, USA) per $10 \mathrm{mg}$ tissue residue. Each sample was incubated at room temperature for $24 \mathrm{~h}$, with stirring. After centrifugation, $100 \mu \mathrm{L}$ of each supernatant was assayed, $1 \mathrm{~mL}$ of Sircol dye reagent that specifically binds to collagen was added to each sample, and the sample was mixed for $30 \mathrm{~min}$. After centrifugation, the pellet was suspended in $1 \mathrm{~mL}$ of the alkali reagent (0.5 molar $\mathrm{NaOH})$ included in the kit, and optical density was evaluated at $540 \mathrm{~nm}$ with a spectrophotometer. Values in the test samples were compared to values obtained with collagen standard solutions provided by the manufacturer, which were used to construct a standard curve. Collagen results were expressed in micrograms.

2.5. Lung Cell Isolation and Myofibroblast Culture. Lungs were removed, minced, and incubated $\left(37^{\circ} \mathrm{C}, 5 \% \mathrm{CO}_{2}\right.$ air $)$ for $45 \mathrm{~min}$ in PBS containing $1 \mathrm{mg} / \mathrm{mL}$ collagenase (C0130, Sigma Aldrich). After enzyme treatment, lung tissue was gently passed through a cell dissociation sieve (Sigma Aldrich) or $40 \mu \mathrm{m}$ nylon mesh filters (Falcon, Becton Dickinson, Franklin Lakes, NJ, USA) and then washed twice in PBS. For myofibroblast culture experiments, lung cells were resuspended in fibroblast culture medium. Cell cultures were incubated at $37^{\circ} \mathrm{C}$ in $5 \%$ humidified $\mathrm{CO}_{2}$. Typically, within 1 week of culture initiation, more than $95 \%$ of the cells are morphologically myofibroblasts.

Cells were passaged every 5 days by dissociating monolayers with a mild trypsin solution (Biological Industries, Beit Haemek, Israel). After initial cultures were established, fibroblasts obtained on passages 2 through 6 were used. 
2.6. Immunostaining of Frozen Tissue Sections. The left lung was removed and frozen in Tissue-Tek O.T.C. compound (Sakuar Finetek, Zoeterwoude, Netherlands). Frozen tissue blocks were cut to provide $4-6 \mu \mathrm{m}$ sections, which were fixed in acetone for $5 \mathrm{~min}$ at $-20^{\circ} \mathrm{C}$ and air dried. Endogenous peroxidase activity was blocked with immersion of sections in $0.3 \% \mathrm{H}_{2} \mathrm{O}_{2}, 0.1 \% \mathrm{NaN}_{3}$ in methanol for $20 \mathrm{~min}$ at room temperature (RT) and washed three times. Nonspecific reactions were blocked with $10 \%$ FCS for $10 \mathrm{~min}$ at RT. After washes with PBS, sections were incubated with rat anti-Thyl (catalog number 550543, BD Biosciences/Pharmingen, San Jose, CA, USA) for $2 \mathrm{~h}$ at RT. After PBS washing, sections were reincubated with universal immunoperoxidase polymer for mouse tissue sections in anti-rat primary antibody (Histofine, Nichirei Biosciences, Tokyo, Japan) for $30 \mathrm{~min}$ at RT and again reincubated for a $10 \mathrm{~min}$ in peroxidase substrate (Dako Kit, Dako, Glostrup, Denmark). The sections were counterstained with hematoxylin (Zymed Kit, Zymed Laboratories, San Francisco, CA) and mounting was added to the slides (Zymed Kit).

2.7. Immunostaining by Flow Cytometry. Cells were harvested by rubber policeman. Myofibroblasts $\left(0.5 \times 10^{6}\right)$ were incubated in FACS buffer (3\% FCS in PBS), with $1 \mu \mathrm{g} / 100 \mu \mathrm{L}$ PE-conjugated anti-Thyl (CD90) mAb (BD Biosciences/ Pharmingen) for $30 \mathrm{~min}$ at RT. The cells were then washed with FACS buffer and analyzed by flow cytometry.

2.8. Myofibroblast Thy1 Crosslinking. Subconfluent myofibroblasts were stimulated with anti-Thyl G7, which has previously been shown to activate T cells [25] or with anti-rat IgG2C $\kappa$ isotype control (BD Biosciences/Pharmingen). Both stimulants were added to myofibroblasts at concentrations ranging from 1 to $20 \mu \mathrm{g} / \mathrm{mL}$, together with recombinant protein $\mathrm{G}$ crosslinker (Sigma Aldrich) at the same concentration.

2.9. Immunofluorescence Staining of CD4, CD8, and CD25 in Lung Sections. Paraffin lung sections were stained as we have previously described in detail [24]. Briefly, deparaffinized lung sections were incubated overnight at $4^{\circ} \mathrm{C}$ with APC-conjugated CD4/FITC-conjugated CD25 or FITCconjugated CD8 (BD Biosciences/Pharmingen), diluted at 1:200 in 1\% BSA PBS Tween 0.05\%. After washing, the slides were analyzed by confocal microscopy (Axio Scope 2; Carl Zeiss AG, Oberkochen, Germany). The fluorescence ratio was analyzed using the Ariol system [26]. The relative staining ratio was calculated by dividing the number of stained cells by the unstained cells in a certain analyzed area.

2.10. Immunohistochemical $\alpha S M A$ Staining of Lung Tissue Sections. Paraffin sections were stained as we have previously described in detail [24]. Briefly, deparaffinized lung sections were incubated overnight at $4^{\circ} \mathrm{C}$ with polyclonal mouse anti-SMA (DAKO) diluted 1:200 in 1\% BSA PBS Tween $0.05 \%$. The Envision Detection System (DAKO) containing secondary anti-mouse horseradish peroxidase-conjugated antibody and $3,3^{\prime}$-diaminobenzidine as a substrate was used for staining detection. The quantitative analysis of $\mathrm{DAB}$ staining was analyzed using the Ariol system. The relative staining ratio was calculated by dividing the number of stained cells by the unstained cells in a certain analyzed area.

2.11. Sirius Red Staining for Collagen (Type I and IV). Deparaffinized lung sections were stained using Picro Sirius Red Stain Kit (Abcam, Cambridge, UK) as was previously described [27]. Red sirius staining was analyzed using the Ariol system. Comparisons were made between the two groups of IT bleomycin. The relative staining ratio was calculated by dividing the number of stained cells by unstained cells in a certain analyzed area.

2.12. RNA Isolation. Total cellular RNA was isolated from myofibroblasts in culture using TriReagent (catalog number T9424, Sigma Aldrich), according to the protocol supplied by the manufacturer. To assess RNA integrity and exclude DNA contamination, an aliquot of each sample was analyzed by electrophoresis on a $1 \%$ agarose gel stained with ethidium bromide. Purity and quantitation of RNA were assessed by spectrophotometer.

2.13. RT-PCR. RNA was reverse transcribed to cDNA using an avian myeloblastosis virus-RT base protocol and random primers, as well as poly dT (Reverse Transcription System; Promega, Madison, WI, USA). One microgram of each sample was uniformly used for reverse transcription. cDNA was diluted in a final volume of $200 \mu \mathrm{L}$ with nuclease-free water.

2.14. Microarray. Total RNA was extracted and used as a template for double-stranded cDNA synthesis as previously described [28].

2.15. Preparation of Labeled cDNA. Labeling was performed using the Low RNA Input Linear Amplification Kit PLUS (One-Color, Agilent, Santa Clara, CA, USA). Briefly, Cy3labeled double-stranded cDNA synthesis was performed using with an oligo(dT)24 primer containing a T7 RNA polymerase promoter site added to the $3^{\prime}$ and cyanine 3 -CTP. cDNA was used as a template for generation of cRNA for hybridization.

2.16. Hybridization of Microarrays. After purification and fragmentation, aliquots of each sample were hybridized to Whole Mouse Genome $4 \times 44$ K Multipack Arrays (Agilent) with probes for 41,000 unique transcripts. In our experience, these arrays have demonstrated superior reproducibility and were recently shown to have superior sensitivity [29]. After hybridization, each array was sequentially washed and scanned (DNA Microarray Scanner, Agilent). Individual arrays were visually inspected for hybridization defects using manufacturer recommended quality control procedures and read out with Agilent Feature Extraction Software. Bioconductor (Bioconductor Project, Seattle, WA, USA) was used to normalize the processed signal [30]. Probes with annotations for entrez gene ID were extracted, and cyclic LOESS was applied to normalize gene expression signals. 
In cases of redundant probes, we took the average over values representing gene expression levels.

2.17. Gene Chip Analysis. Differentially expressed genes were identified by volcano analysis, using a threshold of $>2$-fold changes in expression. $P<0.05$ was considered statistically significant. The analysis of biological processes affected by Thyl in lung, myofibroblasts was performed using OntoExpress software (Open Channel Foundation, Chicago, IL, USA).

2.18. Statistical Analysis. The Mann-Whitney test was performed for comparisons of nonparametric data. When multiple pair-wise comparisons involving two groups were performed, the Bonferroni correction of the $P$ value was used. The nonparametric Kruskal-Wallis test was performed for comparing more than two groups. $P \leq 0.05$ or less was considered statistically significant.

\section{Results}

3.1. Thy1 Expression in Lung Tissue Is Increased at Times of Active Fibrosis following Bleomycin IT but Specifically Decreased in Lung Myofibroblasts. Thyl expression was assessed by immunohistochemistry in frozen lung tissue sections of saline- and bleomycin-treated mice 14 days following instillation, the point of peak fibrosis [4]. When compared to saline-treated mice, Thyl expression in the total lung was increased following bleomycin instillation (Figure 1(a)).

We sought to specifically determine Thyl expression in lung myofibroblasts at different stages following bleomycin injury (1, 3, 7, and 14 days following IT bleomycin). Flow cytometry analysis using PE-conjugated anti-Thyl mAb demonstrated that Thyl expression in lung myofibroblasts is significantly decreased by day 14 (Figures 1(b) and 1(c), segregated histograms), indicating an increase in the proportion of Thy1 ${ }^{-}$myofibroblasts in the total lung myofibroblast population at later stages following bleomycin injury, when fibrosis develops [4].

3.2. Genomic Analysis Shows an Increased Expression of Proinflammatory Genes in Lung Myofibroblasts following Direct Thy1 Crosslinking-Induced Activation. To assess the effects of Thyl activation on lung myofibroblasts, we analyzed gene expression patterns using GeneChip microarrays (Affymetrix, Santa Clara, CA, USA) in samples of RNA extracted from lung primary lung myofibroblasts at different time points before and after Thyl crosslinking by G7 antiThyl $\mathrm{mAb} 10 \mu \mathrm{g} / \mathrm{mL} \mathrm{G} 7$, compared to crosslinking with control matched-IgG isotype, for $30 \mathrm{~min}$ and 1,6 , and 24 hours. Genes with significant expression changes following Thyl crosslinking-induced activation were detected following volcano analysis, using a threshold of $>2$-fold changes of gene expression over the untreated control and $P<0.05$ as the test for significance. Most changes occurred very quickly, from $30 \mathrm{~min}$-to- $1 \mathrm{~h}$ following Thyl stimulation. The number of downregulated genes was larger than the number that was upregulated (Figure 2).
TABLE 1: Molecular pathways downregulated by Thyl.

\begin{tabular}{|c|c|c|}
\hline Pathway name & $\begin{array}{l}\text { \# input genes in } \\
\text { the pathway }\end{array}$ & $P$ value \\
\hline Long adhesion & 13 & $1.02 E-06$ \\
\hline Long-term depression & 6 & $3.85 E-04$ \\
\hline ECM-receptor interaction & 6 & $6.59 E-04$ \\
\hline Small cell lung cancer & 5 & 0.004769 \\
\hline $\begin{array}{l}\text { Regulation of actin } \\
\text { cytoskeleton }\end{array}$ & 8 & 0.005003 \\
\hline Prostate cancer & 5 & 0.005006 \\
\hline Tight junction & 6 & 0.007175 \\
\hline Melanoma & 4 & 0.012134 \\
\hline Bladder cancer & 3 & 0.015551 \\
\hline MAPK signaling pathway & 8 & 0.016136 \\
\hline Axon guidance & 5 & 0.022646 \\
\hline Endometrial cancer & 3 & 0.027335 \\
\hline mTOR signaling pathway & 3 & 0.027335 \\
\hline Gap junction & 4 & 0.02851 \\
\hline Insulin signaling pathway & 5 & 0.029243 \\
\hline Non-small cell lung cancer & 3 & 0.030129 \\
\hline GnRH signaling pathway & 4 & 0.031564 \\
\hline Alzheimer's disease & 2 & 0.033214 \\
\hline Wnt signaling pathway & 5 & 0.03603 \\
\hline p53 signaling pathway & 3 & 0.048047 \\
\hline Glioma & 3 & 0.048047 \\
\hline Cell cycle & 4 & 0.048272 \\
\hline $\begin{array}{l}\text { B cell receptor signaling } \\
\text { pathway }\end{array}$ & 3 & 0.049885 \\
\hline Long-term potentiation & 2 & 0.049885 \\
\hline Neurodegenerative diseases & 2 & 0.050764 \\
\hline Wnt signaling pathway & 7 & 0.001962 \\
\hline $\begin{array}{l}\text { B cell receptor signaling } \\
\text { pathway }\end{array}$ & 4 & 0.00836 \\
\hline VEGF signaling pathway & 4 & 0.011283 \\
\hline $\begin{array}{l}\text { Natural killer cell mediated } \\
\text { cytotoxicity }\end{array}$ & 5 & 0.01976 \\
\hline $\begin{array}{l}\text { Hedgehog signaling } \\
\text { pathway }\end{array}$ & 3 & 0.026203 \\
\hline $\begin{array}{l}\text { Neuroactive } \\
\text { ligand-receptor interaction }\end{array}$ & 7 & 0.036606 \\
\hline $\begin{array}{l}\text { T cell receptor signaling } \\
\text { pathway }\end{array}$ & 4 & 0.037492 \\
\hline $\begin{array}{l}\text { Dorsoventral axis } \\
\text { formation }\end{array}$ & 2 & 0.039028 \\
\hline
\end{tabular}

An analysis of genes related to different biological processes affected by Thyl in lung myofibroblasts was performed using Onto-Express software. Pathways "downregulated" by Thyl crosslinking are shown in Table 1; "upregulated" pathways are found in Table 2. 

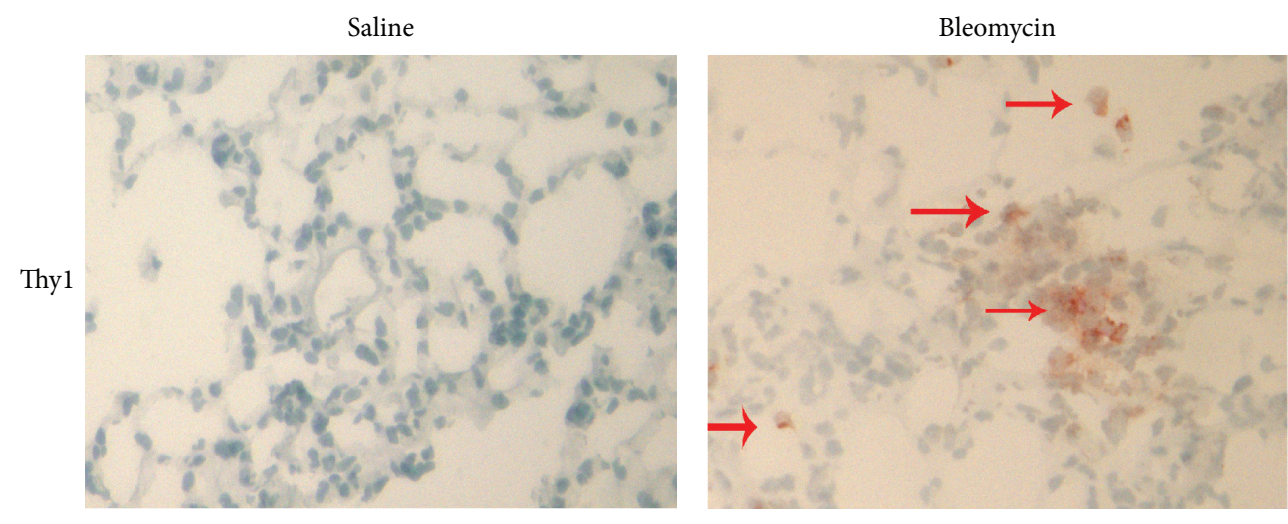

(a)

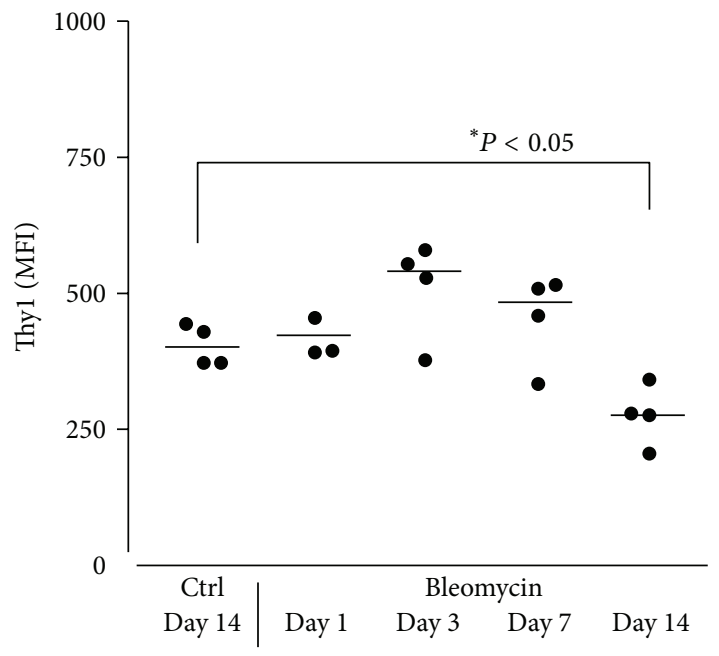

(b)

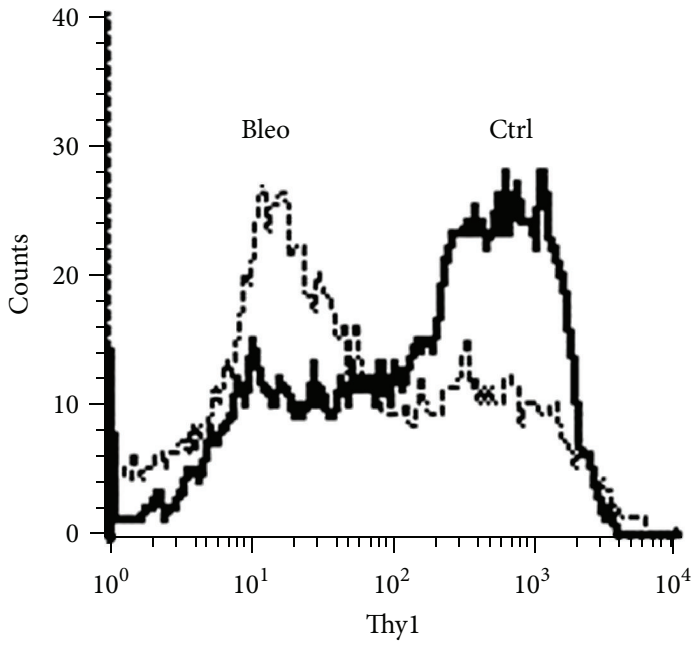

(c)

Figure 1: Thyl-positive total lung cells are increased during experimental fibrosis; however, the proportion of myofibroblasts that are Thylpositive is decreased. (A) Immunohistochemistry of Thyl staining (arrows), in the lungs of saline- vs. bleomycin-treated mice, 14 days following instillation. Representative results. (B) Lung myofibroblasts were isolated from control saline-treated (Ctrl) and bleomycin-treated mice at 1, 3, 7 and 14 days following IT. A graphical presentation of Thyl expression FACS analysis was performed using PE-conjugated antiThyl (CD90) mAb. The differences between control (Ctrl) saline-treated and bleomycin-treated mouse lung myofibroblasts on dayl4 were significant. ${ }^{*} P<0.05, n=4$. (C) Histogram plot showing a representative result of assessment of Thyl expression in myofibroblasts from control (Ctrl) saline-treated mice compared to Thyl expression in myofibroblasts from bleomycin-treated mice at day 14 following IT. Results were similar in 2 different experiments $(n=4)$.

TABLE 2: Molecular pathways upregulated by Thyl.

\begin{tabular}{|c|c|c|}
\hline Pathway name & $\begin{array}{l}\text { \# input genes in the } \\
\text { pathway }\end{array}$ & $P$ value \\
\hline Hematopoietic cell lineage & 3 & 0.020743 \\
\hline ECM-receptor interaction & 3 & 0.020743 \\
\hline $\begin{array}{l}\text { Cytokine-cytokine receptor } \\
\text { interaction }\end{array}$ & 5 & 0.027124 \\
\hline $\begin{array}{l}\text { Antigen processing and } \\
\text { presentation }\end{array}$ & 3 & 0.031685 \\
\hline $\begin{array}{l}\text { Maturity onset diabetes of } \\
\text { the young }\end{array}$ & 2 & 0.003156 \\
\hline $\begin{array}{l}\text { Autoimmune thyroid } \\
\text { disease }\end{array}$ & 2 & 0.026802 \\
\hline
\end{tabular}

In Table 3, we present selectively grouped genes according to pathways that were shown to influence myofibroblast proliferation and extracellular matrix (ECM) production/interaction and differentiation. In addition, changes in myofibroblast inflammatory and immunological genes were grouped. Note that a single gene may participate in more than one pathway.

While most of the genes involved in proliferation, ECM production and interaction, and differentiation were decreased, genes associated with inflammation and immunological functions were increased, following Thyl stimulation. We have previously showed FasL gene overexpression on lung myofibroblasts following Thyl crosslinking, verifying GeneChip results at the RNA level by qPCR and at the protein level by Western blot analyses [28]. 
TABLE 3: Pathways involved in myofibroblast proliferation, differentiation, and interaction with the ECM and immune system that are affected by Thyl.

\begin{tabular}{|c|c|c|c|}
\hline Category & Pathway & Gene name & Fold change $^{* * *}$ \\
\hline \multirow{21}{*}{ Proliferation } & Cell cycle & Anaphase promoting complex subunit 2 & -1.19 \\
\hline & & Cyclin D2 & -1.02 \\
\hline & & CDC23 (cell division cycle 23 yeast homology) & -1.13 \\
\hline & & Transformed mouse 3T3 cell double minute 2 & -1.22 \\
\hline & MAPK signaling pathway & RIKEN cDNA $1500003 \mathrm{O} 03$ gene & -1.03 \\
\hline & & Thymoma viral proto-oncogene 2 & -1.12 \\
\hline & & Activating transcription factor 4 & -1.1 \\
\hline & & Filamin C, gamma (actin binding protein 280 ) & -1.05 \\
\hline & & Protein phosphatase $1 \mathrm{~B}$, magnesium dependent, $\beta$ isoform & -1.06 \\
\hline & & v-raf-leukemia viral oncogene 1 & -1.07 \\
\hline & & Serine/theonine kinase 3 (Ste20, yeast homolog) & -1.2 \\
\hline & & Fibroblast growth factor receptor 1 & -1.13 \\
\hline & Insulin signaling pathway & RIKEN cDNA 4932417H02 gene & -1.22 \\
\hline & & Thymoma viral proto-oncogene 2 & -1.12 \\
\hline & & Brain glycogen phosphorylase & -1.37 \\
\hline & & v-raf-leukemia viral oncogene 1 & -1.07 \\
\hline & & Sorbin and $\mathrm{SH} 3$ domain containing 1 & -1.46 \\
\hline & TGF $\beta$ signaling pathway & Activin receptor IIA & -1.16 \\
\hline & & Protein phosphatase 2 & -1.19 \\
\hline & & Thrombospondin 1 & -1 \\
\hline & Receptors & Angiotensin receptor like 1 & -1.85 \\
\hline \multirow{18}{*}{$\begin{array}{l}\text { ECM production and } \\
\text { interaction }\end{array}$} & Focal adhesion & Thymoma viral proto-oncogene 2 & -1.12 \\
\hline & & Caveolin, caveolae protein 1 & -1.13 \\
\hline & & Cyclin D2 & -1.02 \\
\hline & & Collagen, type I, alpha 1 & -1.02 \\
\hline & & Collagen, type IV, alpha 1 & -1.12 \\
\hline & & Filamin C, gamma (actin bineing protein 280 ) & -1.05 \\
\hline & & Integrin beta 1 (fibronectin receptor beta) & -1.04 \\
\hline & & Laminin, alpha 2 & -1.22 \\
\hline & & v-raf-leukemia viral oncogene 1 & -1.07 \\
\hline & & Thrombonspondin 1 & -1.19 \\
\hline & & Talin 1 & -1.17 \\
\hline & & vav 1 oncogene & -1.59 \\
\hline & & Vinculin & -1.3 \\
\hline & ECM receptor interaction & Collagen, type I, alpha 1 & -1.02 \\
\hline & & Collagen, type VI, alpha 1 & -1.12 \\
\hline & & Dystroglycan 1 & -1.33 \\
\hline & & Integrin beta 1 (fibronectin receptor beta) & -1.04 \\
\hline & & Laminn, alpha 2 & -1.22 \\
\hline \multirow{10}{*}{$\begin{array}{l}\text { Myofibroblast } \\
\text { differentiation }\end{array}$} & $\begin{array}{l}\text { Regulation of actin } \\
\text { cytoskeleton }\end{array}$ & Actin, alpha 2 , smooth muscle, aorta & -1.54 \\
\hline & & Cofilin 1, non-muscle & -1.35 \\
\hline & & Fibroblast growth factor receptor 1 & -1.13 \\
\hline & & Guanine nucleotide binding protein, alpha 13 & -1.2 \\
\hline & & Integrin beta 1 (fibronectin receptor beta) & -1.04 \\
\hline & & v-raf-leukemia viral oncogene 1 & -1.07 \\
\hline & & vav 1 oncogene & -1.59 \\
\hline & & Vinculin & -1.3 \\
\hline & Differentiation & MyoD1 & -1.83 \\
\hline & & $\operatorname{Pax} 7$ & -1.89 \\
\hline
\end{tabular}


TABLE 3: Continued.

\begin{tabular}{|c|c|c|c|}
\hline Category & Pathway & Gene name & Fold change $e^{* * *}$ \\
\hline \multirow{13}{*}{$\begin{array}{l}\text { Inflammation and } \\
\text { immunological function }\end{array}$} & $\begin{array}{l}\text { Hematopoietic cell } \\
\text { lineage }\end{array}$ & CD4 antigen & 1.280914 \\
\hline & & CD8 antigen, alpha chain & 1.74495 \\
\hline & $\begin{array}{l}\text { Antigen processing and } \\
\text { presentation }\end{array}$ & Interferon alpha 13 & 1.57917 \\
\hline & $\begin{array}{l}\text { Cytokine-cytokine } \\
\text { receptor interaction }\end{array}$ & Small chemokine (C-C motif) ligand 11 & 1.913514 \\
\hline & & Chemokine (C-C motif) ligand 17 & 1.571759 \\
\hline & & Chemokine (C-X3-C motif) ligand 1 & 1.0517 \\
\hline & & Interferon alpha 13 & 1.57917 \\
\hline & & Nerve GFR (TNFR superfamily member 16) & 1.451481 \\
\hline & & Nos2 & 2.31 \\
\hline & & Interleukin-1 receptor & -1 \\
\hline & & FasL & 1.71 \\
\hline & & Interleukin-17 receptor & -1.2 \\
\hline & & Cytokine receptor like & -1.17 \\
\hline
\end{tabular}

${ }^{* * *}$ Fold change is shown on a $\log _{2}$ scale.

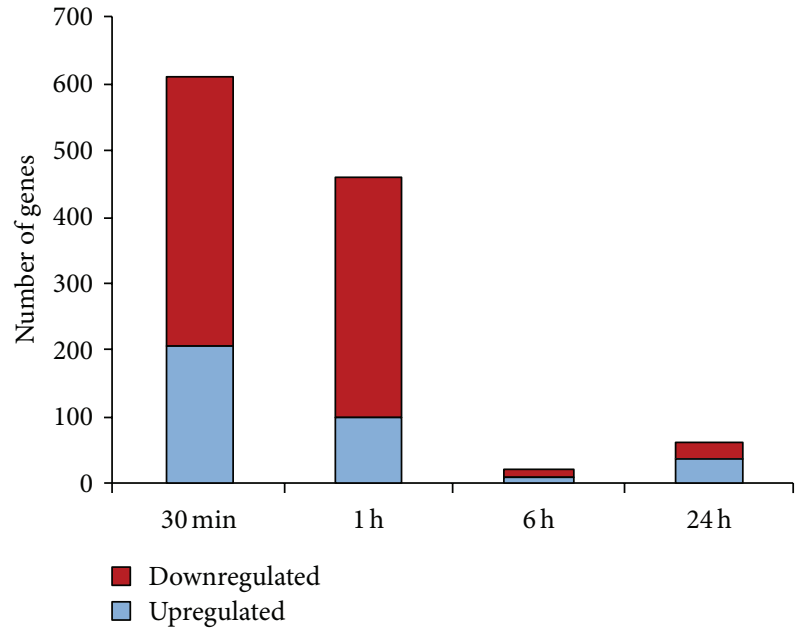

Figure 2: The number of genes in lung myofibroblasts with significant changes in expression at varying time points following Thyl stimulation. Graphic presentation of GeneChip microarray results obtained from primary myofibroblast RNA extracts following stimulation with G7 anti-Thy $\mathrm{mAb}(5 \mu \mathrm{g} / \mathrm{mL})$ or control IgG isotype for $30 \mathrm{~min}, 1 \mathrm{~h}, 6 \mathrm{~h}$, or $24 \mathrm{~h}$. The microarray data were processed by volcano analysis. Upregulated genes (blue), downregulated genes (red).

3.3. Decreased Inflammation with Similar Fibrosis Development following IT Bleomycin in Chimeric Mice with Thy $1^{-}$ Mesenchymal Cells and Normal Lymphocytes Compared to WT Mice with Thy $1^{+}$Mesenchymal Cells and Thy $1^{+}$Lymphocytes. In order to specifically assess the contribution of myofibroblast Thyl downregulation on lung inflammation and fibrosis in vivo in a system excluding Thyl lymphocytes, we used chimeric Thyl-deficient mice. These mice exhibit completely Thyl ${ }^{-}$mesenchymal cells $\left(\alpha \mathrm{SMA}^{+} \mathrm{Thyl}^{-}\right)$, but normal, Thy1 $1^{+}$lymphoctyes $\left(\mathrm{CD}^{+}{ }^{+} \mathrm{Thyl}^{+}\right.$) (Figure 3(a)).
Assessment of lung fibrotic injury by semiquantitative morphological index (SMI) of pathological sections (Figure 3(b)), as well as collagen content (Figure 3(c)), showed no difference between WT and chimeric Thyl-deficient mice when compared to control saline-treated (not shown) mouse lungs; however, we detected a decrease in lung inflammation as determined by bronchoalveolar lavage (BAL) cellularity (Figure 3(d)). In addition, there were no differences between WT and Thyl-deficient mice in either the quantity of $\alpha$ SMApositive cells examined by immunochemistry staining or in collagen I an IV staining, as examined by sirius red staining (Figure 3(E1), Figure 3(E2), Figure 3(F1), and Figure 3(F2)).

\subsection{Increased $C D 4^{+} / C D 25^{+} T$ Regulatory Cells following IT} Bleomycin in Chimeric Mice with Thy ${ }^{-}$Mesenchymal Cells and Normal Lymphocytes Compared to WT Mice with Thy $1^{+}$ Mesenchymal Cells and Thy $1^{+}$Lymphocytes. Having shown decreased inflammation in the lungs of chimeric Thyldeficient mice compared to WT mice, we determined the differences in the inflammatory cell mileux of their lungs. We stained lung sections with anti-CD8 (cytotoxic cells) and costained them with anti-CD4 and anti-CD25 mAbs ( $\mathrm{T}$ regulatory cells). A much larger number of $\mathrm{CD} 4^{+} / \mathrm{CD} 25^{+}$ lymphocytes were detected in chimeric Thyl-deficient mice when compared to WT mice (Figures 4(A1) and 4(A2)); however, there were a comparable number of CD8 cells in WT and Thyl-deficient mice (Figures 4(B1) and 4(B2)).

Taken together, these findings indicate that Thyl on myofibroblasts in vivo has a role in the regulation of the inflammatory process, possibly by increased accumulation of $\mathrm{T}$ regulatory cells following bleomycin injury, with no effect on fibrosis development.

\section{Discussion}

The wide and diverse distribution of Thyl suggests that it has distinct functions that vary between and in some cases even 

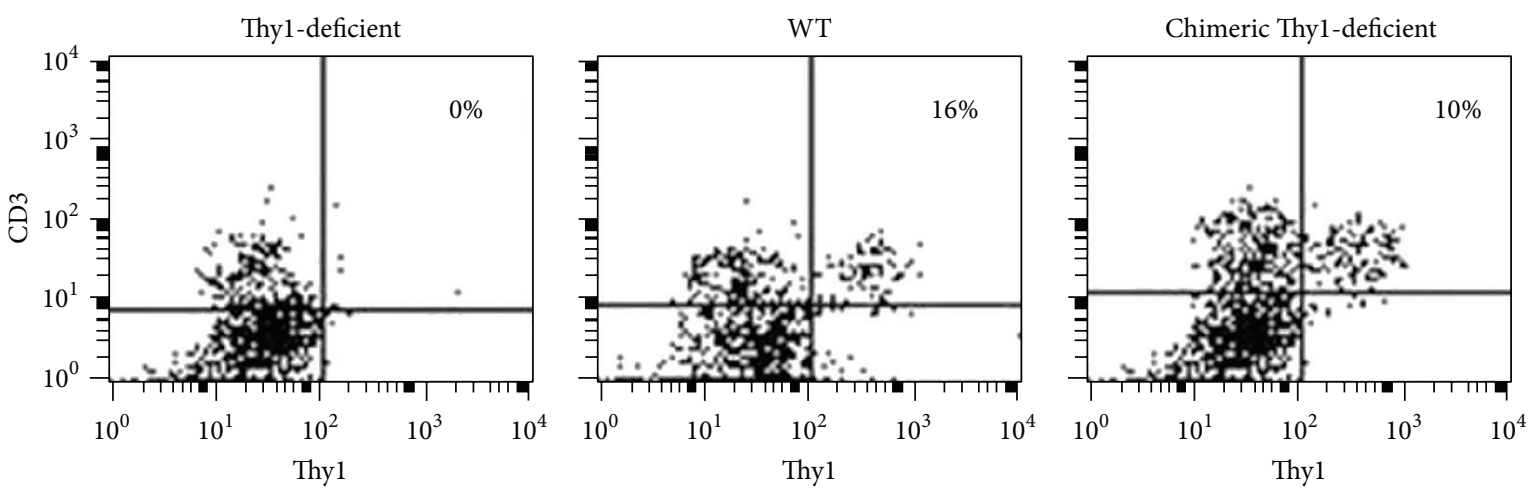

(a)

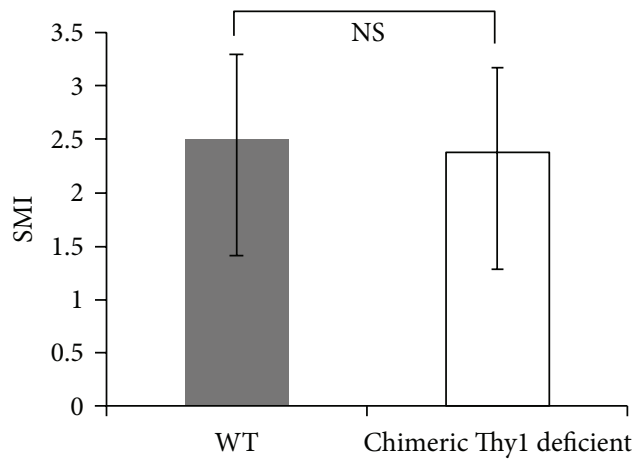

(b)

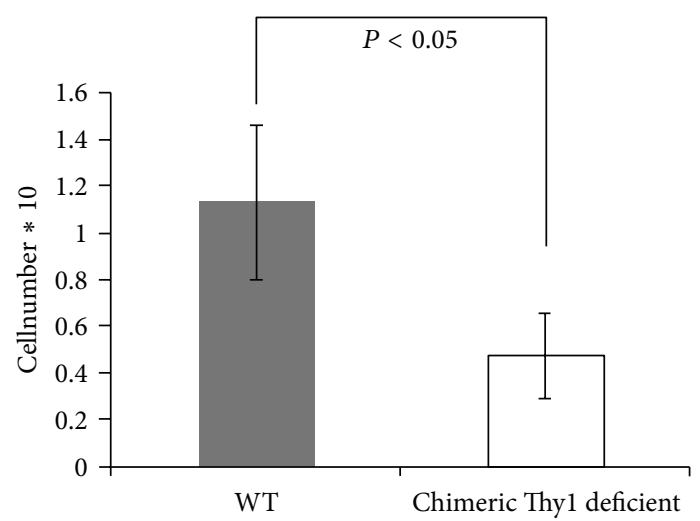

(c)

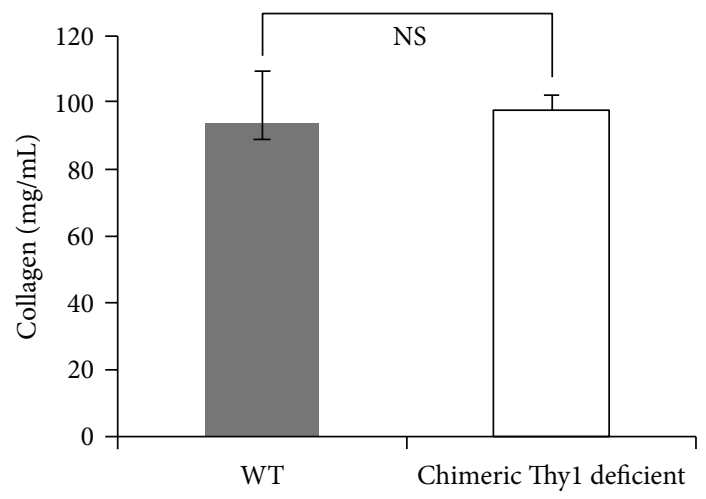

(d)

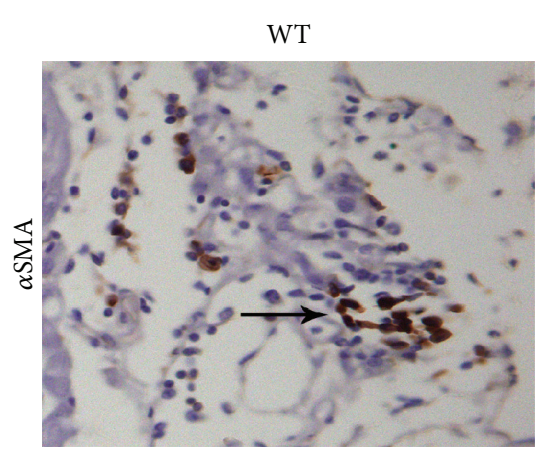

(E1)

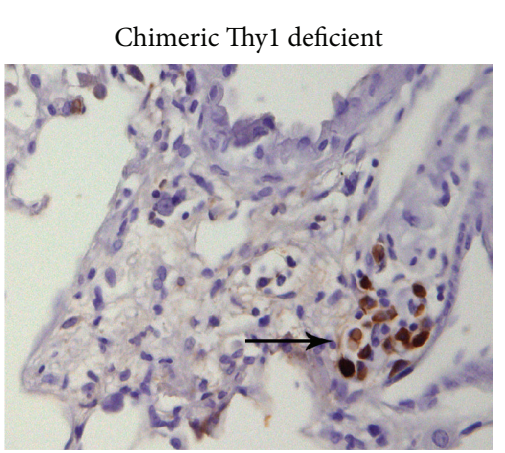

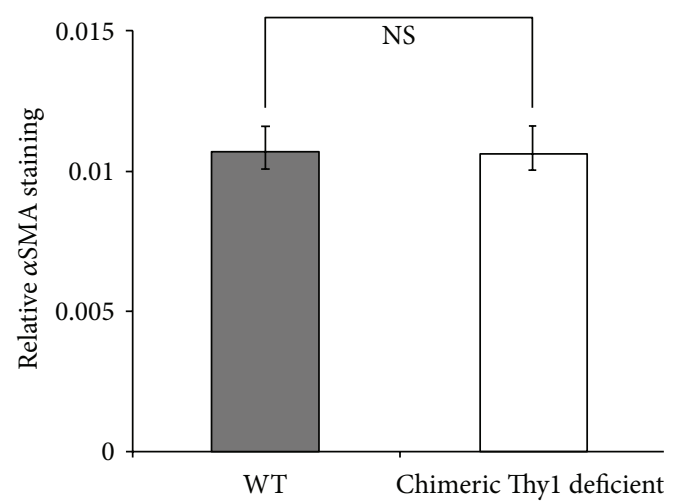

(E2)

(e)

Figure 3: Continued. 

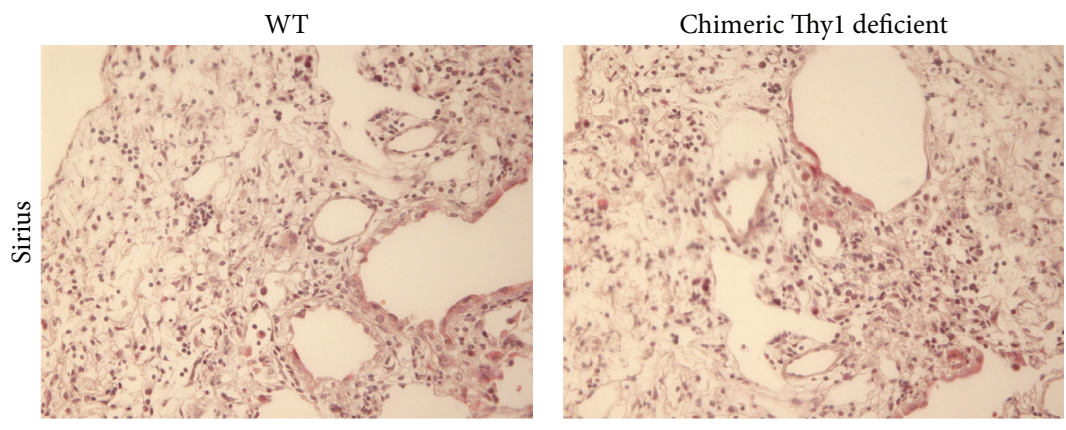

(F1)

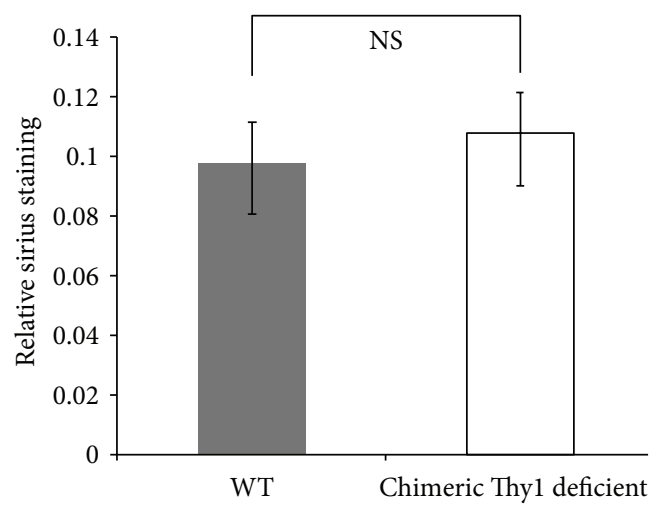

(F2)

(f)

FIGURE 3: Assessment of fibrotic lung injury following bleomycin intratracheal instillation (IT) in wild-type mice with Thyl ${ }^{+}$lymphocytes and Thyl ${ }^{+}$myofibroblasts (WT), and chimeric Thyl-deficient mice with Thy1 ${ }^{+}$WT lymphocytes and Thyl ${ }^{-}$myofibroblasts (chimeric). Thyldeficient mice (DEF) were provided by Prof. R.J. Morris. Chimeric mice were created by whole-body irradiation (750 rad) of the Thyldeficient mice, followed by transplantation with WT Thyl ${ }^{+}$lymphoid cells (chimeric). Wild-type mice underwent whole-body irradiation and reconstitution with WT Thyl ${ }^{+}$lymphoid cells as control (WT). (A) Flow cytometry analysis to detect Thyl ${ }^{+}$immune cells in Thyl-deficient mice (DEF), wild-type mice (WT), and chimeric Thyl-deficient mice with transplanted WT Thyl ${ }^{+}$lymphocytes. Thyl ${ }^{+}$immune cells were identified in blood cells by double staining with PE-conjugated anti-Thyl and FITC-conjugated anti-CD3. (B) Quantitative image analysis of pathological sections in chimeric Thyl-deficient mice (Thyl ${ }^{+}$lymphocytes/Thyl- myofibroblasts, empty bars) and control WT mice (grey bars) $14 \mathrm{~d}$ following IT bleomycin. $n=6 \mathrm{WT}$ and 8 chimeric 2 (C) Analysis of collagen content in lungs using the Sircol assay $14 \mathrm{~d}$ following IT bleomycin in chimeric Thyl-deficient (empty bars) and control WT mice (grey bars). (D) Total BAL cell count in lungs $14 \mathrm{~d}$ following IT bleomycin in chimeric (empty bars) and control WT mice (grey bars) $\left({ }^{*} P<0.05\right)(\mathrm{E} 1, \mathrm{~F} 1) \alpha \mathrm{SMA}$ and sirius staining in lung tissue sections $14 \mathrm{~d}$ following IT bleomycin of chimeric Thyl-deficient (empty bars) and control WT mice (grey bars). (E2, F2) 10 fields of every IHC-slide were digitized using the Ariol machine and semiquantitatively analyzed with the Ariol system. The relative $\alpha$ SMA and sirius staining ratios represent the ratio between numbers of stained and unstained cells in a certain analyzed area. Results were similar in 2 different experiments.

within cell types and tissues, and between similar tissues in different species, indicating that the biological role of Thyl is context-dependent [31].

Using gene chip analysis, we show that Thyl on lung myofibroblasts affects pathways of the nervous system as well as those affecting the development of malignant diseases (Table 1), as previously shown [32-35]. The number of genes that were downregulated by Thyl crosslinking in lung myofibroblasts was higher than the number that were upregulated (Figure 2), indicating that Thyl on lung myofibroblasts appears to be a suppressor factor rather than an activator in most cases. These observations are consistent with previous reports showing an inhibitory effect of Thyl on cell outgrowth of neurites [33] and on tumor growth [32, 34, 35]. Gene expression studies following Thyl crosslinking in vitro may indicate that Thyl could bind to a fixed ligand in vivo, such as an integrin, and/or to another cell type, or perhaps to a matrix ligand. However, our understanding of Thyl ligand and its functions is incomplete and warrants further study.

Our detection of the downregulation of myofibroblast Thyl expression as fibrosis evolves is consistent with findings in several other studies of an inverse correlation between Thyl expression on fibroblasts and the evolution of lung fibrosis $[36,37]$. Of note, one laboratory reported that, under certain conditions, Thyl $^{+}$fibroblasts can produce more collagen compared to Thy1 ${ }^{-}$fibroblasts [38]. Our results also show that myofibroblast Thyl crosslinking upregulates genes promoting inflammation and immunological functions (Table 3). In addition, Thyl upregulated specific genes, including those of chemokines that are responsible for antigen-processing and presentation, as well as those of cytotoxic molecules that promote inflammation and immunological functions (Tables 2 and 3). In particular, we have shown here in the GeneChip analysis (Table 3 ), previously validated by us in Wb, FACS, and qPCR [28], that Thyl activation upregulates FasL expression in lung myofibroblasts, which in turn promotes proinflammatory activity by the recruitment and activation of immune cells [39]. Through this upregulation, Thyl also indirectly induces a cytotoxic cell phenotype in myofibroblasts. We have previously demonstrated that myofibroblasts from bleomycin-treated mice overexpress the FasL molecule and act as effector cells that induce apoptosis in $\mathrm{Fas}^{+}$epithelial cells [24] and lymphocytes [21] via Fas/FasL interaction.

The stronger inflammatory response detected by BAL cellularity in control chimeric WT mice compared to chimeric mice with Thyl ${ }^{-}$myofibroblasts and $\mathrm{WT}\left(\mathrm{Thy}^{+}\right)$lymphocytes could be explained by GeneChip results, which show that Thyl activation, as is the case in chimeric-WT mice, upregulates cytokine gene expression (Table 3). By upregulating cytokine gene expression, Thyl may indirectly promote or induce myofibroblast recruitment of immune cells to the lungs. A lack of Thyl on myofibroblasts, as is the case in Thy1 ${ }^{-}$ chimeric mice, may reduce the level of chemokine protein expression in the lung following bleomycin IT, yielding lower BAL cellularity. 
WT

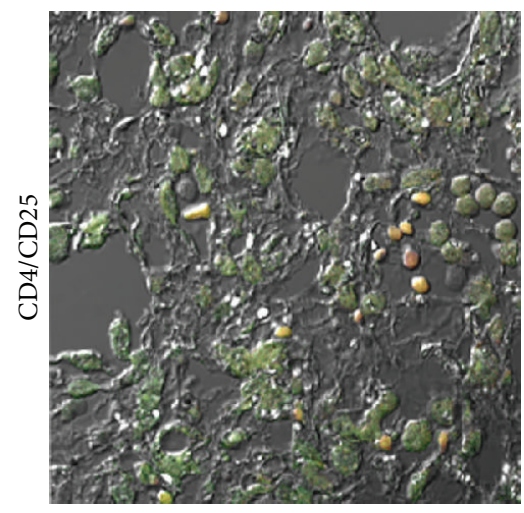

Chimeric Thyl deficient

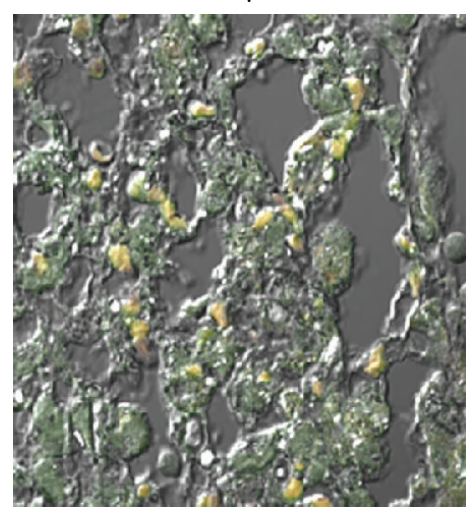

(A1)

(a)
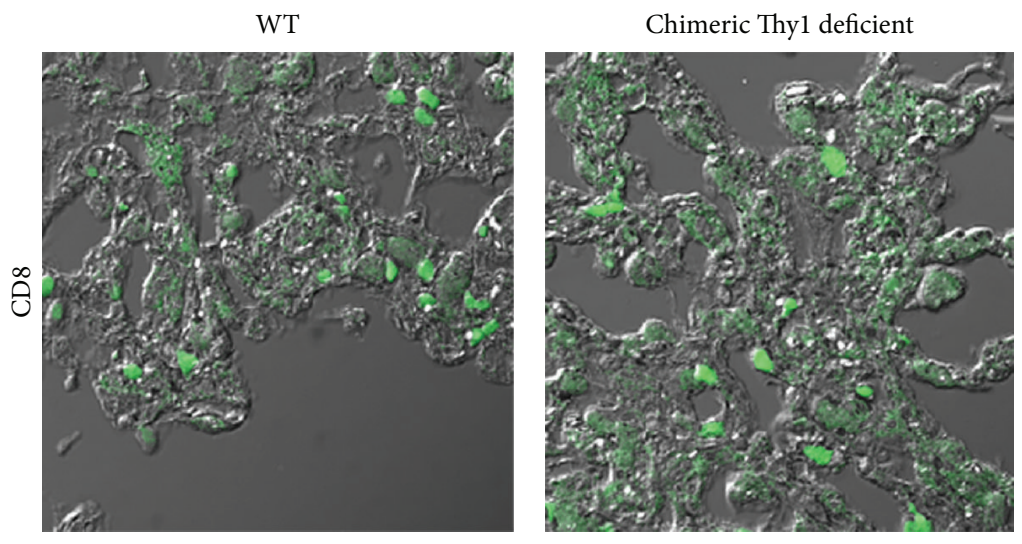

(B1)

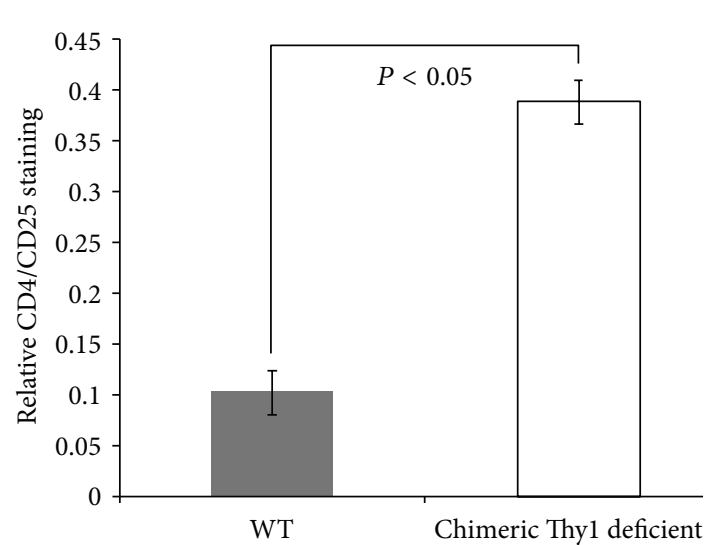

(A2)

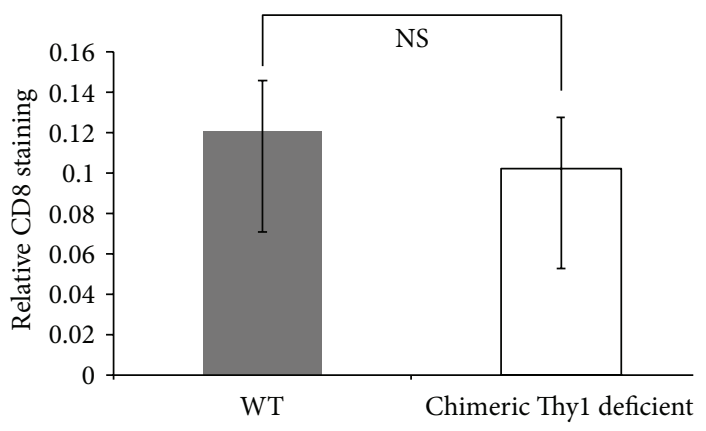

(B2)

(b)

FIGURE 4: Assessment of the T cell population following bleomycin intratracheal instillation (IT) in wild-type mice (WT) (control) with Thyl $^{+}$lymphocytes and Thyl $1^{+}$myofibroblasts, and chimeric Thyl-deficient mice with Thyl $1^{+}$lymphocytes and Thyl ${ }^{-}$myofibroblasts. Chimeric Thyl-deficient mice were created by total body irradiation $(750 \mathrm{rad})$ of Thyl-deficient mice, followed by transplantation with WT Thyl ${ }^{+}$ lymphoid cells. For comparison, wild-type (WT) mice were irradiated and had adoptive transfer with Thyl ${ }^{+}$(WT) lymphoid cells. (A1 and A2) Immunofluorescence of $\mathrm{CD} 4^{+} / \mathrm{CD} 25^{+}$, and (B1 and B2) CD8 staining of mouse lung sections $14 \mathrm{~d}$ following IT bleomycin in chimeric Thyl-deficient mice (empty bars) and control WT mice (grey bars). N $6=5$ WT and 8 chimeric Thyl-deficient. (A1) Nomarski microscopy pictures of CD4/CD25 (yellow) $\left({ }^{*} \mathrm{P}<0.05\right.$ ), and (B1) CD8 (green) staining are presented. (A2 and B2) 10 fields of every immunofluorescence slide were digitized and semiquantitatively analyzed using the Ariol system. The relative staining ratio represents the ratio between numbers of stained and unstained cells in a certain analyzed are. The results were similar in 2 different experiments.

Thyl molecule inhibited gene/s that can be profibrotic (Table 3). Its activation downregulated genes promoting myofibroblast cell proliferation, differentiation, and ECM component production. In addition, we showed that the fraction of the Thyl ${ }^{+}$myofibroblast subpopulation is decreased at day 14 following bleomycin IT. This is consistent with previous reports showing that fibroblasts in the lungs of humans with IPF and of bleomycin-treated mice are predominantly Thyl ${ }^{-}$[36]. Thus, absence of Thyl in myofibroblasts may facilitate their faster proliferation, accumulation, and collagen production and therefore increase lung fibrosis.

The GeneChip analysis may provide some explanation for our in vivo results with chimeric Thyl-deficient mice, which showed no change in fibrosis but did show decreased inflammation, in comparison with chimeric control WT mice that had undergone similar adoptive transfer WT lymphocytes into irradiated WT host mice. These results indicate that when Thyl is deficient in myofibroblasts, as is the case in chimeric Thyl-deficient mice, fibrotic features persist in an in vivo milieu with decreased inflammation.

Hagood et al. reported that Thyl-null mice develop more extensive and more severe lung fibrosis following bleomycin administration than do WT mice [36]. Although this is consistent with our in vitro results, which showed that Thyl activation in lung myofibroblasts downregulates genes promoting cell differentiation and ECM production (Table 3), it 
is not consistent with our in vivo results showing no change in the fibrotic feature between chimeric WT- and Thyl-deficient mice. Thyl is absent from all cells that would otherwise express it in Thyl-null mice, in contrast to our chimeric Thyldeficient mice, which retain Thyl expression on lymphocytes. Because Thyl is normally expressed on murine lymphocytes, it is possible that the severe lung fibrosis following bleomycin IT that develops in Thyl-null mice is not due to changes in fibroblast Thyl expression but rather is due to changes in lymphocyte function [40]. The role of lymphocytes in bleomycin-induced lung fibrosis remains controversial [41$45]$, as does the role of inflammation in IPF [19, 20, 41, 4649]. Decreased inflammation following bleomycin injury, as is the case in the chimeric Thyl-deficient mice with Thyl-deficient myofibroblasts but $\mathrm{Thyl}^{+}(\mathrm{WT}) \mathrm{T}$ cells, may suggest that myofibroblasts downregulate Thyl expression as an additional mechanism allowing their accumulation, promoting immune modulation, and supporting disruption of immune surveillance [21]. Consistent with our results, which show similar fibrosis and similar augmentation of CD8 T cells in chimeric Thyl-deficient and control-WT mice (Figures 4(B1) and 4(B2)), it was shown that $\mathrm{CD}^{+} \mathrm{T}$ cells are associated with development and prognosis of fibrosis [50]. In addition, it was shown that a fibrotic environment in the lung results in an increased abundance of $\mathrm{CD} 4^{+} / \mathrm{CD} 25^{+}$ regulatory $\mathrm{T}$ cells [51]. Our findings show an increase in the number of $\mathrm{CD}^{+} / \mathrm{CD} 25^{+}$regulatory $\mathrm{T}$ cells (Figures $4(\mathrm{~A} 1$ ) and $4(\mathrm{~A} 2))$ in chimeric Thyl-deficient mice, despite the fact that there was no difference in fibrosis between chimeric Thyl-deficient and WT mice. However, the two groups of mice differed in the extent of lung inflammation. It may be possible that differences in the accumulation of regulatory $\mathrm{T}$ cells in these mice cannot influence fibrosis, which was at its peak. However, the increase in T regulatory cells can, and did, have an impact on the extent of inflammation. This can be explained by the complicated interactions between regulatory cells, cytotoxic T cells, and myofibroblasts [52]. The role of Thyl on lymphocytes remains a very interesting issue for further investigation. It may be possible to create chimeric mice with Thy-deficient lymphocytes and WT fibroblasts to pursue this research.

\section{Conclusions}

These findings indicate that, in lung fibrosis, lymphocytes increase Thyl expression while the subset of Thy ${ }^{+}$lung myofibroblasts is decreased. Lung myofibroblasts downregulate Thyl expression to increase their proliferative functions and to reduce the inflammatory milieu, possibly via induction of $\mathrm{CD}^{+} / \mathrm{CD} 25^{+}$regulatory $\mathrm{T}$ cell accumulation, in vivo. Differences in the inflammatory responses of chimeric Thyldeficient mice with Thy1 ${ }^{-}$myofibroblasts but Thy ${ }^{+}$lymphocytes versus WT mice do not affect fibrotic responses other than inflammation. These results indicate a newly identified role for Thyl ${ }^{-}$myofibroblasts and Thyl ${ }^{+}$lymphocytes.

\section{Abbreviations}

BAL: Bronchoalveolar lavage

ECM: Extracellular matrix
FACS: Fluorescence-activated cell sorting

GPI: Glycosylphosphatidylinositol

IP: Intraperitoneal

IPF: Idiopathic pulmonary fibrosis

IT: Intratracheal instillation

PE: Phycoerythrin

qPCR: Quantitative polymerase chain reaction

RT: Room temperature

Thyl ${ }^{-}$: Thyl-negative

Thyl ${ }^{+}$: Thyl-positive

WT: Wild-type.

\section{Conflict of Interests}

The authors have no competing interests to disclose.

\section{Authors' Contribution}

Pazit Y. Cohen contributed to research design and performed all experimental work and primary data analysis, prepared the initial draft of the paper and contributed to revisions. Raphael Breuer contributed to research concept and strategy, supervised the project, and critically revised the paper. Philip Zisman contributed to experiments with IHC and IF. Shulamit B. Wallach-Dayan conceived the research concept and strategies, supervised the study and data analysis, and critically revised the paper. All authors reviewed the final version of the paper and accept responsibility for the accuracy and integrity of the research findings reported here.

\section{Acknowledgments}

The authors thank Anita Kol for the experimental work and Shifra Fraifeld for her editorial assistance in preparing this paper. This work was supported by the Israel Science Foundation, the David Shainberg Fund, and the Israeli Ministry of Health. Microarray experiments were funded by the Dorothy P. and Richard P. Simmons Endowed Chair for Pulmonary Research, University of Pittsburgh Schools of the Health Sciences.

\section{References}

[1] T. E. King Jr., "Diagnostic advances in idiopathic pulmonary fibrosis," Chest, vol. 100, no. 1, pp. 238-241, 1991.

[2] W. A. Marinelli, "Idiopathic pulmonary fibrosis: progress and challenge," Chest, vol. 108, no. 2, pp. 297-298, 1995.

[3] M. Iwano, A. Fischer, H. Okada et al., "Conditional abatement of tissue fibrosis using nucleoside analogs to selectively corrupt DNA replication in transgenic fibroblasts," Molecular Therapy, vol. 3, no. 2, pp. 149-159, 2001.

[4] G. Izbicki, M. J. Segel, T. G. Christensen, M. W. Conner, and R. Breuer, "Time course of bleomycin-induced lung fibrosis," International Journal of Experimental Pathology, vol. 83, no. 3, pp. 111-119, 2002.

[5] K. M. Fries, T. Blieden, R. J. Looney et al., "Evidence of fibroblast heterogeneity and the role of fibroblast subpopulations in fibrosis," Clinical Immunology and Immunopathology, vol. 72, no. 3, pp. 283-292, 1994. 
[6] D. P. Penney, P. C. Keng, S. Derdak, and R. P. Phipps, "Morphologic and functional characteristics of subpopulations of murine lung fibroblasts grown in vitro," Anatomical Record, vol. 232, no. 3, pp. 432-443, 1992.

[7] R. P. Phipps, D. P. Penney, P. Keng et al., "Characterization of two major populations of lung fibroblasts: distinguishing morphology and discordant display of Thy 1 and class II MHC," The American Journal of Respiratory Cell and Molecular Biology, vol. 1, no. 1, pp. 65-74, 1989.

[8] J. S. Hagood, A. Mangalwadi, B. Guo, M. W. MacEwen, L. Salazar, and G. M. Fuller, "Concordant and discordant interleukin-1-mediated signaling in lung fibroblast Thy-1 subpopulations," American Journal of Respiratory Cell and Molecular Biology, vol. 26, no. 6, pp. 702-708, 2002.

[9] J. S. Hagood, P. J. Miller, J. A. Lasky et al., "Differential expression of platelet-derived growth factor- $\alpha$ receptor by Thy-1 ${ }^{-}$and Thy-1 $1^{+}$lung fibroblasts," The American Journal of Physiology: Lung Cellular and Molecular Physiology, vol. 277, no. 1, part 1, pp. L218-L224, 1999.

[10] R. P. Phipps, C. Baecher, J. G. Frelinger, D. P. Penney, P. Keng, and D. Brown, "Differential expression of interleukin $1 \alpha$ by Thy$1^{+}$and Thy-1 $1^{-}$lung fibroblast subpopulations: Enhancement of interleukin $1 \alpha$ production by tumor necrosis factor- $\alpha$," European Journal of Immunology, vol. 20, no. 8, pp. 1723-1727, 1990.

[11] M. R. Silvera and R. P. Phipps, "Synthesis of interleukin-1 receptor antagonist by Thy $-1^{+}$and Thy- $1^{-}$murine lung fibroblast subsets," Journal of Interferon and Cytokine Research, vol. 15, no. 1, pp. 63-70, 1995.

[12] M. R. Silvera, G. D. Sempowski, and R. P. Phipps, "Expression of TGF- $\beta$ isoforms by Thy- $1^{+}$and Thy $-1^{-}$pulmonary fibroblast subsets: evidence for TGF- $\beta$ as a regulator of IL-1-dependent stimulation of IL-6," Lymphokine and Cytokine Research, vol. 13, no. 5, pp. 277-285, 1994.

[13] J. S. Hagood, J. A. Lasky, J. E. Nesbitt, and P. Segarini, “Differential expression, surface binding, and response to connective tissue growth factor in lung fibroblast subpopulations," Chest, vol. 120, 2001.

[14] Y. Zhou, J. S. Hagood, and J. E. Murphy-Ullrich, "Thy-1 expression regulates the ability of rat lung fibroblasts to activate transforming growth factor- $\beta$ in response to fibrogenic stimuli," The American Journal of Pathology, vol. 165, no. 2, pp. 659-669, 2004.

[15] T. H. Barker, H. E. Grenett, M. W. MacEwen et al., "Thy-1 regulates fibroblast focal adhesions, cytoskeletal organization and migration through modulation of p190 RhoGAP and Rho GTPase activity," Experimental Cell Research, vol. 295, no. 2, pp. 488-496, 2004.

[16] A. F. Williams and A. G.-D. Tse, "A glycophospholipid covalently attached to the C-terminus of the Thy-1 glycoprotein," Bioscience Reports, vol. 5, no. 10-11, pp. 999-1005, 1985.

[17] S. Pont, A. Regnier-Vigouroux, S. Marchetto, and M. Pierres, "A Thy-1.1-specific monoclonal alloantibody activates both mouse and rat T cells," Cellular Immunology, vol. 107, no. 1, pp. 64-73, 1987.

[18] A. E. Reif and J. M. Allen, "The Akr thymic antigen and its distribution in leukemias and nervous tissues," The Journal of Experimental Medicine, vol. 120, pp. 413-433, 1964.

[19] S. L. Re, D. Lison, and F. Huaux, "CD4++ T lymphocytes in lung fibrosis: diverse subsets, diverse functions," Journal of Leukocyte Biology, vol. 93, no. 4, pp. 499-510, 2013.
[20] I. G. Luzina, N. W. Todd, A. T. Iacono, and S. P. Atamas, "Roles of T lymphocytes in pulmonary fibrosis," Journal of Leukocyte Biology, vol. 83, no. 2, pp. 237-244, 2008.

[21] S. B. Wallach-Dayan, R. Golan-Gerstl, and R. Breuer, "Evasion of myofibroblasts from immune surveillance: a mechanism for tissue fibrosis," Proceedings of the National Academy of Sciences of the United States of America, vol. 104, no. 51, pp. 20460-20465, 2007.

[22] R. Breuer, I. S. Lossos, R. Or, M. Krymsky, A. Dagan, and S. Yedgar, "Abatement of bleomycin-induced pulmonary injury by cell-impermeable inhibitor of phospholipase A2," Life Sciences, vol. 57, no. 16, pp. PL237-PL240, 1995.

[23] M. Gharaee-Kermani, B. McGarry, N. Lukacs, G. Huffnagle, R. W. Egan, and S. H. Phan, "The role of IL-5 in bleomycin-induced pulmonary fibrosis," Journal of Leukocyte Biology, vol. 64, no. 5, pp. 657-666, 1998.

[24] R. Golan-Gerstl, S. B. Wallach-Dayan, G. Amir, and R. Breuer, "Epithelial cell apoptosis by Fas ligand-positive myofibroblasts in lung fibrosis," American Journal of Respiratory Cell and Molecular Biology, vol. 36, no. 3, pp. 270-275, 2007.

[25] H. Kojima, M. Toda, and M. V. Sitkovsky, "Comparison of Fasversus perforin-mediated pathways of cytotoxicity in TCR- and Thy-1-activated murine T cells," International Immunology, vol. 12, no. 3, pp. 365-374, 2000.

[26] S. Gokhale, D. Rosen, N. Sneige et al., "Assessment of two automated imaging systems in evaluating estrogen receptor status in breast carcinoma," Applied Immunohistochemistry and Molecular Morphology, vol. 15, no. 4, pp. 451-455, 2007.

[27] L. C. U. Junqueira, G. Bignolas, and R. R. Brentani, "Picrosirius staining plus polarization microscopy, a specific method for collagen detection in tissue sections," The Histochemical Journal, vol. 11, no. 4, pp. 447-455, 1979.

[28] P. Y. Cohen, R. Breuer, and S. B. Wallach-Dayan, "Thyl upregulates fasL expression in lung myofibroblasts via Src family kinases," American Journal of Respiratory Cell and Molecular Biology, vol. 40, no. 2, pp. 231-238, 2009.

[29] L. Shi, “The MicroArray Quality Control (MAQC) project shows inter- and intraplatform reproducibility of gene expression measurements," Nature Biotechnology, vol. 24, no. 9, pp. 1151-1161, 2006.

[30] J. Zhang, V. Carey, and R. Gentleman, "An extensible application for assembling annotation for genomic data," Bioinformatics, vol. 19, no. 1, pp. 155-156, 2003.

[31] J. E. Bradley, G. Ramirez, and J. S. Hagood, "Roles and regulation of Thy-1, a context-dependent modulator of cell phenotype," BioFactors, vol. 35, no. 3, pp. 258-265, 2009.

[32] H. L. Lung, D. K. Bangarusamy, D. Xie, and et al, “THY1 is a candidate tumour suppressor gene with decreased expression in metastatic nasopharyngeal carcinoma," Oncogene, vol. 24, no. 43, pp. 6525-6532, 2005.

[33] M.-C. Tiveron, E. Barboni, F. B. Pliego Rivero et al., "Selective inhibition of neurite outgrowth on mature astrocytes by Thy-1 glycoprotein," Nature, vol. 355, no. 6362, pp. 745-748, 1992.

[34] H. R. Abeysinghe, Q. Cao, J. Xu et al., "THY1 expression is associated with tumor suppression of human ovarian cancer," Cancer Genetics and Cytogenetics, vol. 143, no. 2, pp. 125-132, 2003.

[35] H. R. Abeysinghe, S. J. Pollock, N. L. Guckert et al., "The role of the THY1 gene in human ovarian cancer suppression based on transfection studies," Cancer Genetics and Cytogenetics, vol. 149, no. 1, pp. 1-10, 2004. 
[36] J. S. Hagood, P. Prabhakaran, P. Kumbla et al., "Loss of fibroblast Thy-1 expression correlates with lung fibrogenesis," American Journal of Pathology, vol. 167, no. 2, pp. 365-379, 2005.

[37] J. C. McIntosh, J. S. Hagood, T. L. Richardson, and J. W. Simecka, "Thyl (+) and (-) lung fibrosis subpopulations in LEW and F344 rats," European Respiratory Journal, vol. 7, no. 12, pp. 21312138, 1994.

[38] S. Derdak, D. P. Penney, P. Keng, M. E. Felch, D. Brown, and R. P. Phipps, "Differential collagen and fibronectin production by Thy $1^{+}$and Thy $1^{-}$lung fibroblast subpopulations," The American Journal of Physiology - Lung Cellular and Molecular Physiology, vol. 263, no. 2, pp. L283-L290, 1992.

[39] J. O'Connell, "Immune privilege or inflammation? The paradoxical effects of fas ligand," Archivum Immunologiae et Therapiae Experimentalis, vol. 48, no. 2, pp. 73-79, 2000.

[40] S. Beissert, H.-T. He, A.-O. Hueber et al., "Impaired cutaneous immune responses in Thy-1-deficient mice," The Journal of Immunology, vol. 161, no. 10, pp. 5296-5302, 1998.

[41] M. Helene, V. Lake-Bullock, J. Zhu, H. Hao, D. A. Cohen, and A. M. Kaplan, "T cell independence of bleomycin-induced pulmonary fibrosis," Journal of Leukocyte Biology, vol. 65, no. 2, pp. 187-195, 1999.

[42] B. B. Moore, J. A. McDonald, S. Sitterding, R. Paine, and G. B. Toews, "T cells protect against bleomycin-induced pulmonary fibrosis (abstract)," American Journal of Respiratory and Critical Care Medicine, vol. 159, p. A213, 1999.

[43] G. A. Rossi, S. Szapiel, V. J. Ferrans, and R. G. Crystal, "Susceptibility to experimental interstitial lung disease is modified by immune- and non-immune-related genes," The American Review of Respiratory Disease, vol. 135, no. 2, pp. 448-455, 1987.

[44] S. K. Sharma, J. A. MacLean, C. Pinto, and R. L. Kradin, "The effect of an anti-CD3 monoclonal antibody on bleomycininduced lymphokine production and lung injury," American Journal of Respiratory and Critical Care Medicine, vol. 154, no. 1, pp. 193-200, 1996.

[45] R. S. Thrall, J. R. McCormick, S. H. Phan, R. M. Jack, and P. A. Ward, "The effect of antilymphocyte globulin on the development of hleomycin-induced pulmonary fibrosis in the rat," The American Review of Respiratory Disease, vol. 83, supplement, p. 119, 1979.

[46] J. Gauldie, "Inflammatory mechanisms are a minor component of the pathogenesis of idiopathic pulmonary fibrosis," American Journal of Respiratory and Critical Care Medicine, vol. 165, no. 9, pp. 1205-1206, 2002.

[47] G. P. Downey, "Resolving the scar of pulmonary fibrosis," The New England Journal of Medicine, vol. 365, no. 12, pp. 1140-1141, 2011.

[48] E. Fireman, N. Vardinon, M. Burke et al., "Predictive value of response to treatment of T-lymphocyte subpopulations in idiopathic pulmonary fibrosis," European Respiratory Journal, vol. 11, no. 3, pp. 706-711, 1998.

[49] E. Corsini, M. I. Luster, J. Mahler, W. A. Craig, M. E. Blazka, and G. J. Rosenthal, "A protective role for T lymphocytes in asbestosinduced pulmonary inflammation and collagen deposition.," American Journal of Respiratory Cell and Molecular Biology, vol. 11, no. 5, pp. 531-539, 1994.

[50] Z. Daniil, P. Kitsanta, G. Kapotsis et al., "CD8+ T lymphocytes in lung tissue from patients with idiopathic pulmonary fibrosis," Respiratory Research, vol. 6, article 81, 2005.

[51] G. Du, L. Jin, X. Han, Z. Song, H. Zhang, and W. Liang, "Naringenin: a potential immunomodulator for inhibiting lung fibrosis and metastasis," Cancer Research, vol. 69, no. 7, pp. 32053212, 2009.

[52] S. Sakaguchi, K. Wing, Y. Onishi, P. Prieto-Martin, and T. Yamaguchi, "Regulatory T cells: how do they suppress immune responses?” International Immunology, vol. 21, no. 10, pp. 11051111, 2009. 


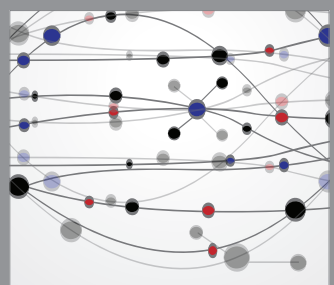

The Scientific World Journal
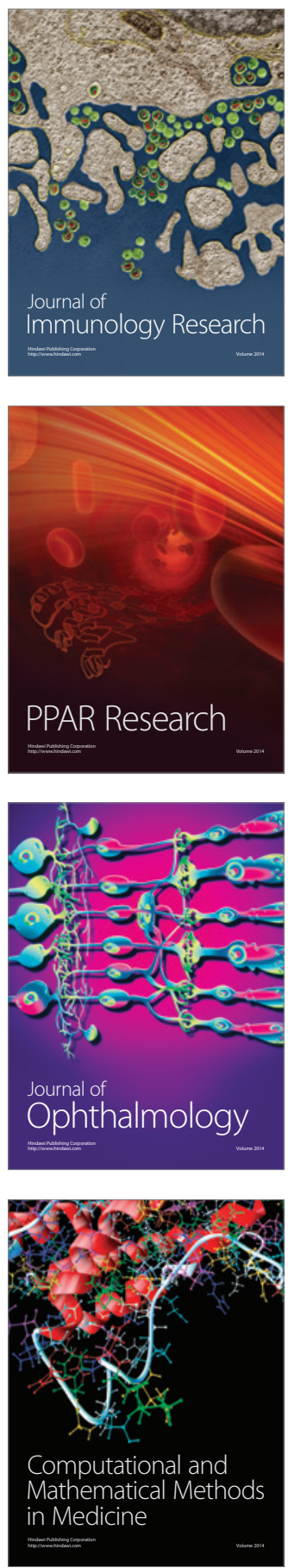

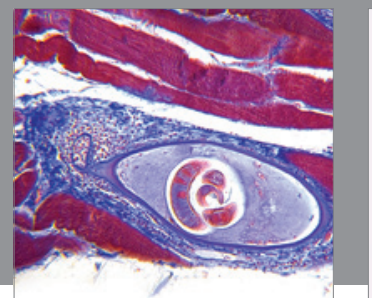

Gastroenterology

Research and Practice
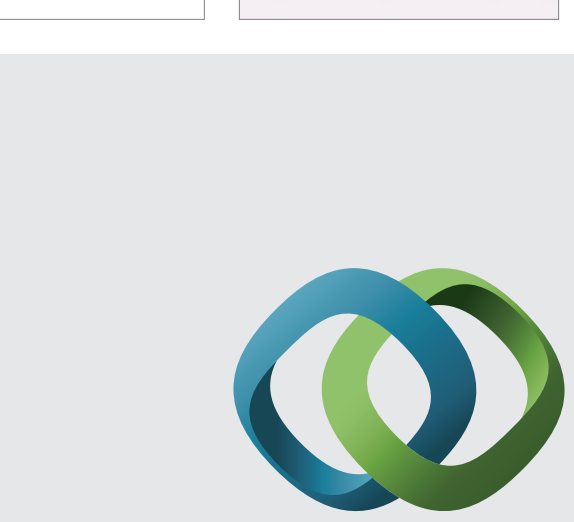

\section{Hindawi}

Submit your manuscripts at

http://www.hindawi.com
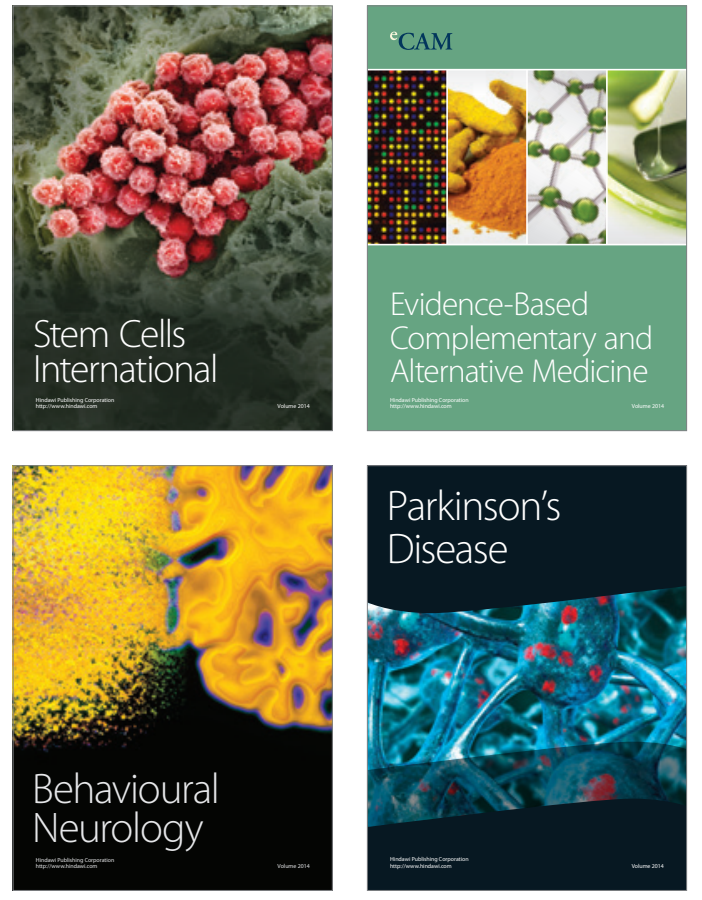
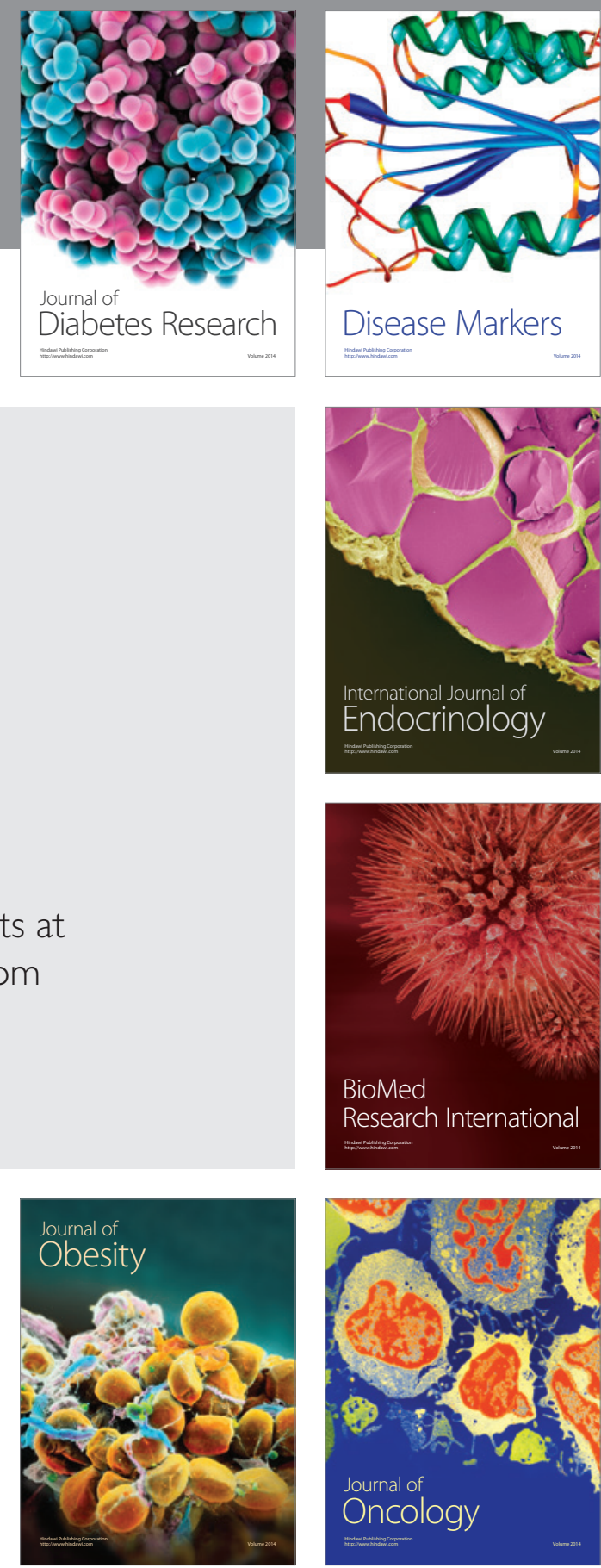

Disease Markers
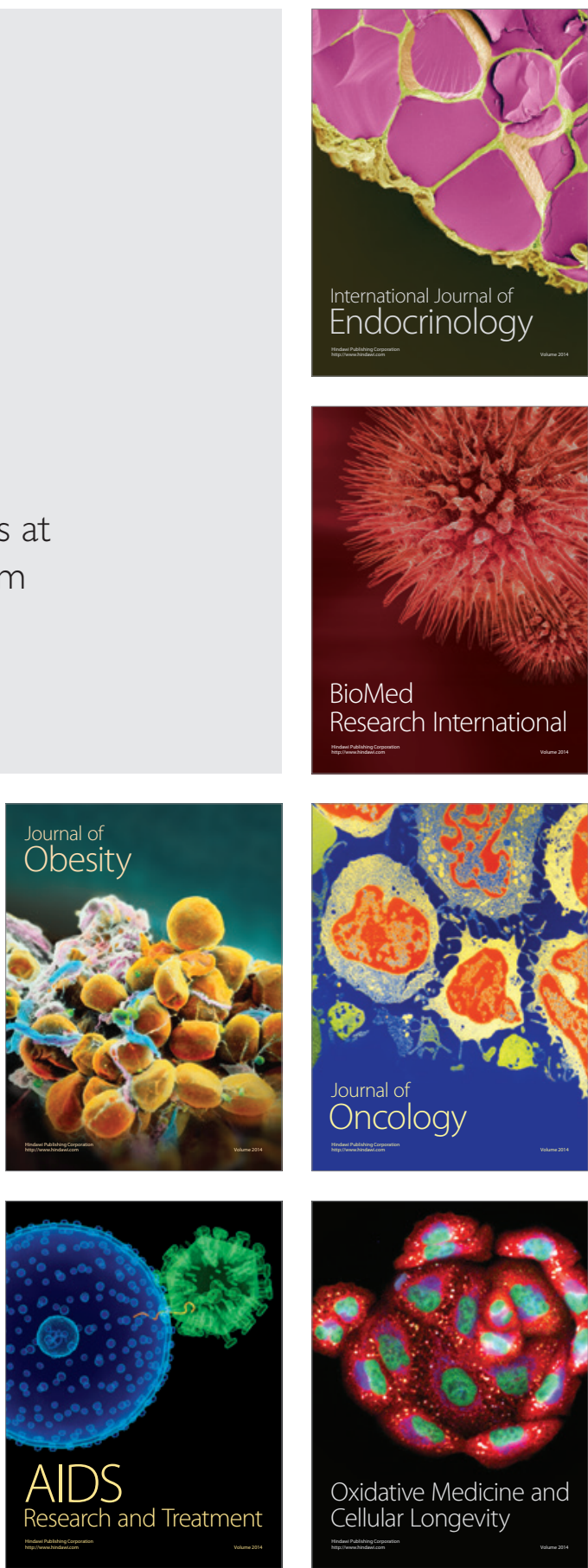